Short Communication

\title{
Preparation of Activated Carbon Electrode from Pineapple Crown Waste for Supercapacitor Application
}

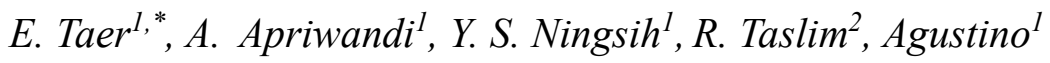 \\ ${ }^{1}$ Department of Physics, University of Riau, 28293 Simpang Baru, Riau, Indonesia \\ ${ }^{2}$ Departement of Industrial Engineering, State Islamic University of Sultan Syarif Kasim, 28293 \\ Simpang Baru, Riau, Indonesia. \\ *E-mail: erman.taer@lecturer.unri.ac.id
}

doi: $10.20964 / 2019.03 .17$

Received: 11 November 2018 / Accepted: 31 December 2018 / Published: 7 February 2019

\begin{abstract}
A pineapple crown activated carbon (PCAC) was prepared from pineapple crown waste using one step carbonisation and physical activation method for electrode super capacitor cells. The pineapple crown waste was also activated by using $\mathrm{KOH}$ activation in a ratio of $1: 1$ to the total mass. The precarbonised PCAC has a thermal resistance temperature of $300^{\circ} \mathrm{C}$ while the carbonised one has high Brunauer-Emmett-Teller (BET) with a surface area of $700 \mathrm{~m}^{2} \mathrm{~g}^{-1}$, a pore volume of $0.362 \mathrm{~m}^{3} \mathrm{~g}^{-1}$ and an average pore diameter of $22 \mathrm{~nm}$. The surface morphology of pineapple crown electrode shows a good fibre structure with a diameter of $42-73 \mathrm{~nm}$. The electrochemical properties of supercapacitor cells have an excellent specific capacitance which is as high as $150 \mathrm{~F} \mathrm{~g}^{-1}$ while its energy and power densities are $5.2 \mathrm{Wh} \mathrm{Kg}^{-1}$ and $42 \mathrm{~W} \mathrm{Kg}^{-1}$, respectively
\end{abstract}

Keywords: pineapple crown; activated carbon; biomass

\section{FULL TEXT}

(C) 2019 The Authors. Published by ESG (www.electrochemsci.org). This article is an open access article distributed under the terms and conditions of the Creative Commons Attribution license (http://creativecommons.org/licenses/by/4.0/). 